\title{
SPF Test from Baccaurea lanceolata Muell.Arg Fruit Isolates
}

\author{
Samsul Hadi $^{1}$, Subagus Wahyuono ${ }^{2}$, Ag. Yuswanto ${ }^{2}$, Endang Lukitaningsih ${ }^{2}$ \\ ${ }^{1}$ Postgraduate, Universitas Gadjah Mada, Yogyakarta, Indonesia \\ (Department of Pharmacy, Universitas Lambung Mangkurat, Banjarmasin, Indonesia) \\ ${ }^{2}$ Lecture, Faculty of Pharmacy, Universitas Gadjah Mada, Yogyakarta, Indonesia
}

\begin{abstract}
Not many researches on a fruit of limpasu (Baccaurea lanceolata Muell. Arg ) were found, while the use by tribal hamlets in Kalimantan already became a daily routine before they went into the field with the way made powder and smeared on the face. Therefore, the research on active substances needs to be done. For this study, we prepared two isolates which coded as $\mathrm{K} 2$ and CE, $\mathrm{K} 2$ from qualitative test negative isolates phenolic groups was identified by spray $\mathrm{FeCl}_{3}$, whereas qualitative test positive isolates were coded as $\mathrm{CE}$ and detected by a nitrogen-containing reagents dragendorf spray. The K2 isolate from SPF test resulted an SPF value of 3.2 at a concentration of $0.2 \mathrm{mg} / \mathrm{ml}$, while CE isolate was given a value of SPF 5.0 at a concentration of $0.2 \mathrm{mg} / \mathrm{mL}$. According to sensitivity skin test on rabbit skin, both $\mathrm{K} 2$ and $\mathrm{CE}$ isolated were given the value below I, indicated the isolates were found to not irritate. This study proposes the potential from Baccaurea lanceolata Muell.Arg fruit isolates to be developed as a sunscreen for UV-protection.
\end{abstract}

Keywords : Baccaurea lanceolata Muell.Arg, SPF test, sensitivity skin test

\section{INTRODUCTION}

One of the utilization of natural ingredients for skin care by the tribe Banjar in South Kalimantan is from limpasu (Baccaurea lanceolata) fruit which frequently used topically on the skin for protecting the skin from sunburn. The use of limpasu as a protective skin from the sun can be tested out with several approaches to determine the value of a sunscreen with SPF (Sun Protection Factor).

Previous study were conducted on several species such as $B$. angulata baccaurea (better known as dayak blimbing) which performed antioxidant activity based on DPPH assay with $\mathrm{IC}_{50}$ value of $53.68 \mathrm{mg} / 100$ (Jauhari, et al., 2013), while this result correlated with another study by Ahmed, et al. (2015) who revealed that B. angulata methanol extract had several major phenolic flavonoids, with total carotenoid contents that greater in the fruit rather than the other part. Another related study was also revealed on $B$. ramiflora containing isolates $6 '$ O-vanilloylisota-chioside with antioxidant capacity (DPPH) 36.9 ppm (Yang, et al., 2007). And B. sapida performed $\mathrm{IC}_{50}$ value for inhibition of lipid per oxidation by using ammonium thiocyanate with $0.84 \mathrm{mg} / \mathrm{mL}$, iron ion chelating capacity of fruit B.sapida $0.47 \mathrm{mg} / \mathrm{mL}$ (Prakash, 2012).

\section{MATERIALS AND METHODS}

\section{Sample and Reagent}

The fruit of limpasu (baccaurea lanceolata) from South Kalimantan was prepared as much as 30 $\mathrm{kg}$. The other materials that used for this study were 70\% ethanol, n-hexane, ether, ethyl acetate, methanol, distilled water, reagents dragendorf, $\mathrm{FeCl} 3$ 1\%, p.a N-hexane, ethyl acetate p.a, methanol p.a, biocream ${ }^{\circledR} 7$. The animal object that prepared in this study was mice and rabbits.

\section{Isolation}

Limpasu fruit was dried and macerated with $70 \%$ ethanol, later fractionated with n-hexane, ether, ethyl acetate and methanol constitutively. The ethyl acetate fraction, then proceeds with isolation using PTLC (Preparative Thin Layer Chromatography) with the mobile phase n-hexane p.a and ethyl acetate p.a.

*Corresponding author e-mail: samsul.hadi.apt@gmail.com 


\section{SPF Test}

The isolate from limpasu fruit was made into various series of concentration with methanol p.a. as solvent. The absorbance spectra of the sample was determined by UV spectrophotometer using wavelength of 290-320 nm. The higher the SPF score, the more protection from the material offered against UV radiation causing sunburns. According to FDA in 2011, materials with SPF value of 2-14 can be claimed to prevent sunburn, meanwhile above 15 can be claimed to reduce the risk of skin cancer and early skin aging.

\section{Sensitivity Skin Test}

The sample was obtained by base Biocream ${ }^{\circledR}$ then applied to the skin of rabbits for observation in 72 hours. First irritation index value was determined by adding up the score of erythema and edema. The earliest irritation index calculation was done by calculating the average score of the observations at 24, 48 and 72 hours.

Based on Hayes (2001), index irritation was scored as below:

- $0-1$ : almost doesn't irritation

- $1-2:$ mild irritation

- 2-5: medium irritation

- Up 5: heavy irritation

\section{RESULTS AND DISCUSSION}

The maceration of dried limpasu fruit resulted 300 grams of viscous extract, then after fractionation with n-hexane, ether, ethyl acetate, and methanol gave filtrate as much as 95, 50, 20, and 50 grams respectively and 85 grams of insoluble macerate. Ethyl acetate fraction was found out as the most active fraction (the data not shown), thus ethyl acetate fraction was isolated further using preparative TLC with the mobile phase n-hexane p.a.: ethyl acetate p.a (4: $1 \mathrm{v} / \mathrm{v})$, which was isolated in 8/16 Rf die isolates with $\mathrm{K} 2$ and RF 4/16 code that isolates the $\mathrm{CE}$ code, then tested qualitatively with the spray reagent. K2 isolates qualitative test beneficial $\mathrm{FeCl}_{3}$ whereas explicit isolates Dragendorf CE.

Based on the qualitative test using $\mathrm{FeCl}_{3}$ for $\mathrm{K} 2$ isolate, the TLC plate showed a spontaneous reaction to the reagent spray, indicated that the isolate was not able to be concluded into specifically group containing phenolic, however after being heated, the $\mathrm{K} 2$ isolated showed patches of black, which showed that the isolates did not contain phenolic groups but only -OH groups at most, possibly a class of terpenes containing $\mathrm{OH}$ groups. Meanwhile in $\mathrm{CE}$ isolate, after reaction with Dragendorf reagent showed spontaneous reaction which suspected that the isolate might contain several nitrogen atoms. The supported data from absorbance (data not shown) revealed that either $\mathrm{K} 2$ isolates or CE isolates had $\lambda$ max below $254 \mathrm{~nm}$ which indicated the compound which contained in the isolates were possibly from class of terpenes.

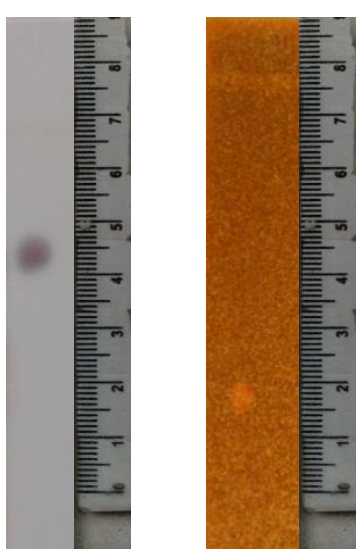

Figure I. Qualitative test isolates K2 and CE 
Table I. (A) isolates SPF values K2 with three unusual concentrations. (B) The value of SPF CE isolates with three distinctive concentrations

\begin{tabular}{cc}
\hline Concentration $\mathbf{~ m g / m l}$ & SPF value \\
\hline $0, \mathrm{I}$ & $\mathrm{I}, 5$ \\
0,15 & $\mathrm{I}, 7$ \\
0,2 & 3,2 \\
\hline
\end{tabular}

(A)

SPF test was conducted on $\mathrm{K} 2$ and $\mathrm{CE}$ isolates at concentration of $0.1 \mathrm{mg} / \mathrm{mL}, 0.15 \mathrm{mg} / \mathrm{mL}$, and 0.2 $\mathrm{mg} / \mathrm{mL}$ with $\mathrm{SPF}$ value of each shown in Table 1. The highest SPF value was found in $\mathrm{CE}$ isolate although with the same concentration between isolates $\mathrm{K} 2$ and $\mathrm{CE}$ dies $0.2 \mathrm{mg} / \mathrm{mL}$.

On the sensitivity test of $\mathrm{K} 2$ isolate that conducted on rabbits at a concentration of 0.2 $\mathrm{mg} / \mathrm{mL}$ in the base show the average below 1 at 48 and 72 hours of observation, which demonstrated this isolate could be used maximally for 24 hours to

\begin{tabular}{cc}
\hline Concentration $\mathbf{~ m g / m l}$ & SPF value \\
\hline $0, \mathrm{I}$ & 2,5 \\
0,15 & 3,2 \\
0,2 & 5,0 \\
\hline
\end{tabular}

(B)

be protected from the sun and light sensitive air. A value of 1 is also interpreted that this isolate was relatively not irritated.

Meanwhile, on the sensitivity test from $\mathrm{CE}$ isolate conducted on rabbits at a concentration of 0.2 $\mathrm{mg} / \mathrm{mL}$ in the base shows the average below 1 at the 72-hour observation, showing that the isolate was better to be used maximum for 48 hours to be safe at sensitive sun light and air. A value of below 1 is showed the isolate was found be not relatively irritant.

Table 2. The sensitivity skin test of $K 2$ isolate with the concentration of $0.2 \mathrm{mg} / \mathrm{mL}$ (the highest SPF value) on the skin of rabbits

\begin{tabular}{lcccc}
\hline \multicolumn{1}{c}{ Rabbit } & \multicolumn{1}{c}{ Observation in hours } & Average \\
\hline & 24 & 48 & 72 & 0 \\
Control rabbit & 0 & 0 & 0 & 0.66 \\
Rabbbit I & 0 & 1 & I & 0.66 \\
Rabbit II & 0 & 1 & I & 0.66 \\
Rabbit III & 0 & $\mathrm{I}$ & & 0.66 \\
\hline Avarage rabbit I ,II, III & & & I \\
\hline
\end{tabular}

Table 3. The sensitivity skin test of CE isolate with the concentration of $0.2 \mathrm{mg} / \mathrm{mL}$ (the highest SPF value) on the skin of rabbits

\begin{tabular}{lcccc}
\hline \multicolumn{1}{c}{ rabbit } & \multicolumn{1}{c}{ Observation in hours } & average \\
\hline & 24 & 48 & 72 & 0 \\
Control rabbit & 0 & 0 & 0 & 0.33 \\
Rabbit I & 0 & 0 & 1 & 0.33 \\
Rabbit II & 0 & 0 & 1 & 0.33 \\
Rabbit III & 0 & 0 & 1 & 0.33 \\
\hline Avarage rabbit I ,II, III & & & & \\
\hline
\end{tabular}




\section{CONCLUSION}

These study revealed that $\mathrm{K} 2$ and $\mathrm{CE}$ isolates gave the SPF value of 3.25 respectively at a concentration of $0.2 \mathrm{mg} / \mathrm{mL}$. On the sensitivity skin test on rabbit, both $\mathrm{K} 2$ and $\mathrm{CE}$ isolates gave the average value below 1 , which indicated that the isolates were found to not relatively irritate.

\section{REFERENCES}

Ahmed, I.A., Mikail, M.A., Bin Ibrahim, M. , Bin Hazali, N., Rasad, M.S.B.A., Ghani, R.A., et al., 2015, Antioxidant Activity and Phenolic Profile of Various Morphological Parts of Underutilised Baccaurea angulata Fruit, Food Chem., I 72, 778-787.

Hayes, A.W., 200I, Principles and Methods of Toxicology, 4th Edition, Philadelphia: Taylor and Francis.

FDA, 201I, Questions and Answers: FDA announces new requirements for over-the-counter (OTC) sunscreen products marketed in the U.S., https://www.fda.gov/drugs/resourcesforyou/c onsumers/buyingusingmedicinesafely/understa ndingover-thecountermedicines/ucm258468.htm.

Jauhari, N.K., Ibrahim, D., Ibrahim, M., Yahya, M.N.A., Nor, N.M., Isa, K.A.M., et al., 2013, Proximate Composition and Antioxidant Activity of Dried Belimbing Dayak (Baccaurea angulata) Fruits, Sains Malaysiana, 42(2), 129 134.

Prakash, D., Upadhyay, G., Gupta, C., Pushpangadan, P. and Singh, K.K., 2012, Antioxidant and Free Radical Scavenging Activities of Some Promising Wild Edible Fruits, Int. Food Res. J., 19(3), II09-1II6.

Yang, X.W., He, H.P., Ma, Y.L., Wang, F., Zuo, Y.Q., Lin, H., et al., 2010, Three New Vanilloid Derivatives from the Stems of Baccaurea ramiflora, Planta Med., 76(I), 88- 90. 